\title{
The political theory of parties
}

Fabio Wolkenstein, Assistant Professor, Department of Political Science, Aarhus University and Adjunct Researcher in Political Theory, Department of Political Science, University of Amsterdam

This article reviews the recent body of political theory scholarship on political parties and partisanship. It discusses, on the one hand, approaches that focus on partisanship as an associative practice, and on the other hand approaches that focus on the party as an institution. The article argues that, while the two approaches usefully complement each other, concentrating on partisanship at the expense of party risks paying insufficient attention to the institutional structures that connect partisans to the state and allow them to exercise power. This is problematic, however, since it is especially parties as institutions whose functionality tends to be doubted. The political theory of parties is incomplete without an agenda for party reform.

Generally speaking, scholars working in the fields of political theory and philosophy are not especially interested in political parties (see Rosenblum 2008). In the anglophone analytic tradition of political philosophy, the major debates of the day continue to be debates around different concepts, conceptualisations and applications of justice. These debates tend to touch on broad and general moral problems and have relatively little to do with the ordinary business of elections, contestation, and mobilisation. But even in the comparatively smaller world of democratic theory, which tends to be much more interested in political practice, parties are widely shunned. As two observers noted in 2008, in an article tellingly called "Democratic Theorists and Party Scholars: Why They Don't Talk to Each Other, and Why They Should," "modern democratic theory is noticeably silent on the question whether political parties have a legitimate place and function in a democracy" (Biezen and Saward 2008, 22).

Take the field of deliberative democracy. To cite just one striking example, the recently published Oxford Handbook of Deliberative Democracy (Bächtiger et al. 2018), which promises to represent the field in its full breadth, includes chapters on virtually all things one could possibly connect with the topic of deliberation except parties. Consider also recent theoretical work on representation. Here, the main concern appears to be with expanding the possibilities of representation and the signification of that term as broadly as possible, notably beyond elections, parties and traditional representative institutions (e.g., Rehfeld 2009; Rosanvallon 2008; Saward 2010; Näsström 2015; for a critique, see Schweber 2016). Or think of the burgeoning theoretical literature on the notion of civil disobedience and other practices of protest and disruption (e.g., Butler 2015; Celikates 2016; Scheuerman 2016; Smith 2017). This work often sees parties as part of the problem 
against which protest should be directed: the undemocratic establishment that is considered responsible for all sorts of democratic ills. The background intuition, in Kalyvas's words (2008, 297, emphasis added), is that "phenomena such as civil disobedience, irregular and informal movements, ... protests, insurgencies, street fighting, and illegal upheavals are as (if not more) important to democracy as normal politics." This point is not just descriptive, but normative: the party form is often seen as inferior to more spontaneous, non-institutionalised forms of political agency (for an overview and critique, see Dean 2016).

This latter body of literature points to a potential reason for why political parties are widely considered unworthy of theoretical attention: together with representative democracy at large, parties are widely thought to have become dysfunctional. As Peter Mair $(2013,1)$ framed the concern, parties have "become so disconnected from the wider society, and pursue a form of competition that is so lacking in meaning, that they no longer seem capable of sustaining democracy in its present form" (also see Ignazi 2017). Thus, the impulse to theorise about anything and everything but parties may be seen as responding to a critical analysis of existing representative-political institutions, one that regards party democracy as broken, and infers from this a need to search for alternative ways to exercise democratic agency in representative, participatory, etc. ways, over and above "normal politics."

In part as a reaction to this, a small but growing body of literature in political theory seeks to illuminate why parties were ever thought to be desirable in the first place, and why there is still good reason to think that parties and partisanship provide indispensable forms of democratic agency. Since the mid-2000s, theorists such as Nancy Rosenblum (2008), Russell Muirhead (2014), Jonathan White and Lea Ypi (2016), and Matteo Bonotti (2017) have developed novel theoretical accounts of party that seek to re-establish the latter firmly as a subject of political theory and philosophy. Their defences underline in distinctive fashion what parties add to democracy, and why party-less democracy is ultimately a spurious idea.

This new political theory of parties proves to be the exception to the otherwise general rule that political theorists neglect parties. In this article, I want to offer a critical review of the key theoretical arguments in this emerging research field. I begin by running through the just-mentioned work of Rosenblum, Muirhead, White and Ypi, and Bonotti. These are arguably the most rigorous and influential theoretical studies on the topic of parties that have been conducted so far. While they differ in many respects, what unites the four books in question is their strong focus on partisanship as an associative practice, at the expense of party as an institutional form. In a second step, I shift perspective and look at work that takes the opposite tack, privileging the party over practices of partisanship. Examining this scholarship, I suggest that there are good empirical reasons for focusing less on partisanship and more on parties, which has to do with the institutional transformation parties have undergone over the past forty years or so - a transformation that reinforces and stabilises the widely-lamented disconnect between parties and their constituents (cf. Biezen and Saward 2008). 
The recent revival of party theory

As I have already indicated, the "new" political theory of parties is still a relatively small and emerging field. It began with a number of articles published in the $2000 \mathrm{~s}$, in which a number of prominent theorists - spearheaded by Nancy Rosenblum - tried to connect the topic of parties and partisanship to distinctively normative concerns in democratic theory and political theory more generally (e.g., Rosenblum 2000; Muirhead 2006; White and Ypi 2010).

In what follows, I want to run through these authors' later, more developed works, notably Rosenblum's major 2008 book On the Side of the Angels: An Appreciation of Parties and Partisanship, Muirhead's 2014 book The Promise of Party in a Polarized Age and White and Ypi's 2016 book The Meaning of Partisanship. I will also discuss the most recent like-minded contribution, Matteo Bonotti's 2017 work Partisanship and Political Liberalism in Diverse Societies. I selected these four books because they are the main recent English-language treatises on the topic and are widely seen as forming the backbone of the new party literature in political theory. ${ }^{1}$ In a later section I also engage with even more recent work, notably Jodi Dean's Crowds and Party (2016) and Frances Rosenbluth and Ian Shapiro's Responsible Parties (2018).

Between democratic realism and history of political thought: Rosenblum and Muirhead

Beginning with Rosenblum's ambitious and wide-ranging On the Side of the Angels, this consists of an intellectual history of what Rosenblum calls "antipartyism," as well as a positive argument for the "moral distinctiveness" of party identification. Perhaps most relevantly, the historical part of the book shows with utmost clarity why major modern philosophers such as Hobbes and Rousseau deemed parties a danger to the common good: those philosophers tended to conceive the political community as a unified whole, with only one (clearly identifiable) common good. By implication, anyone proposing different interpretations of the common good - as parties typically do - is a threat to the stability if not the survival of the political community.

As Rosenblum persuasively shows, this way of thinking about politics also makes itself visible in contemporary phenomena such as authoritarian one-partyism (think of the Chinese Communist Party) or, indeed, and more subtly, in the majoritarianism of referenda, which entails, in her felicitous formulation, "bowing to the decision of the half plus one as if it were the decision of the whole" (Rosenblum 2008, 50). One might likewise think of the much-discussed phenomenon of "populism," which, at least according to one

\footnotetext{
${ }^{1}$ This is of course not to suggest that other contributions (e.g., Bader 2014; Ebeling 2016; Landis 2018; Teorell 1999) are not relevant. I focus on the book-length treatments simply because they represent the most comprehensive and internally consistent efforts of re-establishing parties as a topic of political theory, being as they are the culmination of multiple years of research on the topic.
} 
popular interpretation, is characterised by the view that "there can be no such thing as a legitimate opposition" and only one correct interpretation of the common good (Müller 2014, 487).

When did parties experience their first moments of appreciation, and what arguments were put forward in their defence? Arguably the most important historical defender of parties - an author whose work is a central reference point in the work of virtually all other contemporary party theorists - is the conservative Whig philosopher and politician Edmund Burke. Burke is credited with being the first modern thinker to advance a distinctively positive conception of parties as "a body of men united for promoting by their joint endeavours the national interest, upon some particular principle in which they are all agreed" (Burke [1770] 1998, 271). The point to note is that, in Burke's view, parties are not merely expressions of private interests who aim to exercise power to advance their well-being and corrupt the common good, as many previous thinkers feared. They are associations based on a shared interpretation of what the common good requires. In making this point, Burke in important ways rehabilitated the notion of party (an association that pursues the common good), distinguishing it from the notion of faction (an association that pursues the self-interest of a few). While for a long time these two concepts were essentially treated as one, Burke provided good reasons to keep them separate, and to favour party over faction.

Rosenblum shows that Burke had yet another argument in support of parties. Targeting concerns with political instability arising from partisan conflict, Burke "recognized organized parties as a political development that might mitigate rather than aggravate the evils that lead to violent political strife" (Rosenblum 2008, 121). The point was to see them as "regular, institutional substitutes for private intrigue as well as open rebellion," a "checking apparatus" that tames more unregulated, possibly anarchical forms of political conflict by bringing it "into the frame of government," regularising it and eventually bestowing legitimacy onto it (Rosenblum 2008, 121). This defence of parties, Rosenblum notes, "was both enormously innovative and modest," breaking as it did with the received wisdoms of Burke's time (Rosenblum 2008, 121). "Better debate in parliament than kill each other on the street" was the basic idea.

Burke's first argument still has a controversial ring to it. After all, many contemporary writers keep conceptualising parties as agents that seek to promote narrow, factional interests instead of the good of the whole (a point Rosenblum demonstrates by reviewing standard conceptions of party in political science). One possible explanation for this is that much of the scholarly groundwork on which contemporary research builds goes back to the age of mass democracy, where even the staunchest defenders of parties (e.g., Hans Kelsen) have associated parties with the organised collective pursuit of group interests.

This view no doubt carries a lot of plausibility: the first major parties that emerged as suffrage was gradually extended in the mid and late $19^{\text {th }}$ century, were parties that sought to represent the interests and values of particular social groups, such as workers or Catholics. To say that these parties had no vision for the political community at large 
would still seem reductive, however. Most of them certainly had such a vision, and hence also approximated a Burkean conception of party. Think, for example, of the innumerable debates around the proper nature of and political path towards a socialist society that took place between orthodox Marxists and social-democratic revisionists in the early Socialist or Social Democratic parties (Berman 2006). These debates were no doubt about the good of society at large.

To the degree that these early parties, especially the Socialist ones, departed from their initial ambitions of violent revolutionary overthrow and accepted the liberal-democratic system of "regulated rivalry," they also came closer to the distinctive ideal of partisanship Rosenblum defends. The first component part of this ideal is, following Burke, the endorsement of regulated rivalry:

"Partisans situate themselves in [a] system of political opposition. ... That means at its most basic that [they] do not look to liquidate, erase, or permanently disorganize the opposition or represent them as public enemies. Partisans are not bent on mutual destruction. An opposition seen as mistaken, corrupt, unfair, or unjust does not rise to illegitimacy. It is not outlawed" (Rosenblum 2008, 363).

All the while, partisans - whether in minority or majority position - "recognize that their standing is partial and temporary. That is, partisanship entails commitment to the provisional nature of political authority, its periodic recreation" (Rosenblum 2008, 363). Partisan victories, in Rosenblums view, are therefore never "final," in the sense that political conflict ends when one has won an absolute majority of votes. Because partisans are aware of their "partiality," they also accept iterative shifts in the vote distribution and, by extension, the possibility of losing.

This points towards the second and most interesting component of Rosenblum's normative account of partisanship: the dialectical relationship between advancing a political vision based on an interpretation of the common good, on the one hand, and the acknowledgment of one's party's partial standing, on the other. What does this mean exactly? It means that while "partisans claim to be offering a satisfactory account of justice and what needs to be done for the nation as a whole," and "want the opposition to be defeated (or enlightened)," they "do not want or expect the elimination of political lines of division. They do not claim that their party speaks for the whole. They are always partial, and however ardent and devoid of scepticism there is a limit and reticence to partisan claims. Even in power, they are not the nation" (Rosenblum 2008, 364).

This recognition of partiality, notes Rosenblum, encapsulates nothing less than the "the categorical moral distinctiveness of party ID" (Rosenblum 2008, 364). Partisans (at their best) recognise that their standing is partial, if not for principled reasons - a deep commitment to the values of liberal democracy - then for prudential ones, i.e., facing the prospect of being in opposition at some point. Together with their promotion of particular 
political visions for society as a whole, these [aspects] of partisanship "connect partisans intimately to the practices of representative democracy (Rosenblum 2008, 366):

"Partisanship is avowed attachment, publicly enacted, to the form of political partiality and opposition characteristic of representative democracy. A distinctive political identity that is self-consciously partial and accepts its status as a part is significant, of course, because partisans alone among social groups are prepared for their own to assume responsibility for governing" (Rosenblum 2008, 366).

The Promise of Party in a Polarized Age, the book of Rosenblum's close collaborator (e.g., Muirhead and Rosenblum 2006) Russel Muirhead's, is framed with an emphatic focus on the contemporary political challenges facing the U.S. Muirhead's starting point, as indicated by his book's title, is the rather extreme polarisation found between Democrats and Republicans today. To quickly get a sense of the problem, consider that, in a recent survey, about 4 percent of the respondents from each party say that they view the opposition as "downright evil." Even more strikingly, asked whether violence would be justified if the opposing party wins the 2020 presidential election, " 18.3 percent of Democrats and 13.8 percent of Republicans said violence would be justified on a scale ranging from 'a little' to 'a lot'" (Edsall 2019). In light of this, it would hardly be surprising if Muirhead eventually resorted to a Burke-style defence of the ultimate importance of "regulated rivalry."

His book is much more ambitious than that, however. For Muirhead wants to both reconstruct an empirically-grounded ideal of partisanship and affirm the value, if not necessity, of "political contestation [that] reaches to fundamental questions about the definition of the community itself" (Muirhead 2014, 54). Let us begin with the ideal and then move on to the question of contestation. In sum, Muirhead's ideal of partisanship comprises two elements. The first he calls loyalty, which involves both the "memory" of the accomplishments of the partisans of the past and "patience" concerning the gradual realisation of the parties' aims and goals, which are inevitably long-term. The second element is the element of compromise, a quality that partisans should display both within their party and without it, i.e., both when deliberating with one's fellow partisans and when debating with rival partisans.

This ideal of partisanship expands on Rosenblum's in that it puts special emphasis on the cross-temporal dimension of the practice (what Muirhead captures under the heading of "loyalty"). Otherwise it captures very similar intuitions as Rosenblum's, notably the recognition of partiality that (should) lead(s) to self-limitation. When it comes to the role of conflict in democratic politics, on the other hand, Muirhead conceptualises the tension between an ethical partisanship of compromise and agonistic modes of political contestation more radically than anyone else in the field. He does so by advancing a position that is avowedly sceptical of ideals of rationality and impartiality that are widely shared in political theory, and thought to be part of the political culture of developed 
liberal-democratic societies. As he explains in chapter 2 of his book, in line with what he calls "traditional partisanship" we should welcome the fact that partisan conflicts are not merely about justice but about substantive conceptions of the good life, with all the affective, identitarian and divisive baggage such conceptions typically come with.

This view also leads Muirhead to argue that every political community - including liberal ones - is ultimately best conceived as a partisan community, meaning that we should regard even the most foundational values of a society as the outcome of partisan conflicts (rather than, say, universal moral truths that stand above ordinary politics) and, hence, as potentially open to contestation (68-76). Seemingly affirming Ernst-Wolfgang Böckenförde's famous "dictum" that the liberal, secularized state lives by prerequisites, which it cannot itself guarantee, Muirhead indeed claims that the tendency of partisans to "to reengage foundational agreements by extending their application to a new age" (75) implies that these foundational agreements also do not define the boundaries of partisanship. Just as partisanship is about substantial questions the good life, it is not necessarily constrained by what seem to be the nation's basic creed. All the while, however, partisanship ought still to instantiate the norms of loyalty and compromise that make it an admirable and valuable practice in the first place.

One way of looking at Muirhead's book is to see it as accepting that partisanship may permissibly be radical in aims and conflictual in its enactment so long as partisans in the end retain a basic "ethical" outlook that makes them inclined to compromise with their rivals. As he put it in an earlier article that formed the basis of the book:

"[e]thical partisans ... hope their side wins, yet know that victory should never be total. ... The most admirable partisans are brave enough to stand up publicly for what they see, yet are capacious enough to know that what they see is not the whole of things. ... Such partisans stand, but not unflinchingly. They would flinch - at the thought that one side would win a victory that might bring an end to partisanship itself" (Muirhead 2006, 722).

So just like in Rosenblum's ideal of partisanship, Muirhead's ethical partisans are also inclined to self-limitation and the recognition of one's own partiality. Attractive though this sounds, one wonders to what extent a partisanship that challenges the fundamentals of a liberal society can be compatible with what ultimately sounds like a liberal commitment to accept pluralism and engage in self-limitation when push comes to shove.

What is interesting (and quite unique) about Muirhead's book is that he not just argues for a particular interpretation of what partisanship "at its best" may look like, but also reflects in a systematic fashion on how U.S. partisanship can be reformed so as to overcome the current political impasse. Not only does he foreground concrete role-models of positive partisanship (e.g., Democratic Sen. Ted Kennedy of Massachusetts and Republican Sen. Alan Simpson of Wyoming), he also argues that if "more citizens, especially those currently drawn to an independent stance, [were to] become partisans" (148), 
the effect would be the necessary moderation of partisanship. Put simply, he advises currently politically uncommitted Americans to enter partisan conflict for the sake of better politics. Finally, he advocates a "civic education for partisanship" (169) that should allow citizens to better understand "the ideologies that increasingly define them: liberalism and conservatism" (169), thus cultivating a capacity among citizens to be "capacious enough to know that what they see is not the whole of things." In these ways, the "better" partisanship that the U.S. so desperately needs should become feasible.

\section{A philosophical turn: White and Ypi, and Bonotti}

Jonathan White and Lea Ypi's book The Meaning of Partisanship (2016) is much more philosophical in orientation, taking, as the authors note, a "theoretical turn." White and Ypi's main goal is to develop a general account of partisanship that "emphasizes principled constraints on partisan action" (155). By this, they mean that a desirable form of partisanship needs to be coupled with an account of political justification that grounds "a commitment to persuade others of their views through the appeal to reasons that can be generally shared" (3, emphasis added). Partisans, in other words, should advance their political demands "with the aim of demonstrating public appeal," moving "beyond a particularist viewpoint" (61). In this way, they can contribute in important ways to "the articulation and channeling of principled disagreements by rendering political projects visible and susceptible to comparison" (76), and thereby also contribute to "to identifying the general interest rather than undermining it" (48). Such partisanship is the opposite of mere power politics, and, in White and Ypi's view, it is indispensable in democratic societies, where the exercise of power must be responsive to broader normative concerns of public justification in order to be considered legitimate.

What is interesting about White and Ypi's conception of partisanship is how much work they expect public reason constraints to do. It is straightforwardly plausible to defend an adhesion to public reason norms as crucial for achieving compromises between partisans that are not just power-based bargains but more principled agreements on desirable goals that can jointly be pursued (ch. 7). It is much more controversial, on the other hand, to suggest that the kind of partisanship that seeks to publicise its view of the common good in generalisable terms is also compatible with firm political commitment that induces agents to refuse revising their political views even in the face of total political defeat (see ch. 4). Without denying the central role of political commitment in vibrant democratic societies, public justification is bound to become one-way communication when it involves presenting views that have been rejected by great numbers of people as instantiating generally shared values and principles (think e.g. of Soviet communism). Sometimes revising one's political views may have independent value.

Contrasting White and Ypi's position with Muirhead's argument is instructive to understand what is distinctive about it: while Muirhead appeals to certain partisan role models and emphasises the contribution of civic education in improving partisanship, 
White and Ypi resort to an argument about a general moral duty to justify political claims in generalisable and reciprocal terms - perhaps the essence of the philosophy of public reason (for an overview, see Chambers 2010). It is in this sense that their book is more philosophical than the other contributions I discuss here: a certain familiarity with particular strands of post-Rawlsian political theory is certainly a pre-requisite for receiving their arguments as persuasive. This is not just true with respect to their arguments about public justification, but also in relation to their creative application of theories of associative obligations (ch. 5) and intergenerational justice to the political party (ch. 6). In the chapters on these topics, White and Ypi suggest that the idea of party makes sense only when we assume that those implicated in and committed to it are bound by moral obligations that extend over time: akin to what Muirhead refers to as "loyalty" (see above), partisans are said to have a moral duty to ensure that the achievements of the partisans of the past are sufficiently honoured, on the one hand, and that the principled spirit of the party is retained for future generations of like-minded partisans, on the other hand.

A similar concern for the relationship between parties and democratic theories of public reason also animates Matteo Bonotti's book Partisanship and Political Liberalism in Diverse Societies (2017). Bonotti's aim is even more explicitly philosophical and theoretical than White and Ypi's: he seeks to establish the place of parties in John Rawls's influential philosophy of political liberalism, rescuing "Rawls's theory from the widespread accusation that it is inhospitable to real-world politics, and especially to party politics" (175). To achieve this goal, Bonotti works with admirable care and precision through the complexities inherent in the later Rawls's understanding of public reason, as laid out in Political Liberalism (1993), suggesting that "there is in fact a correspondence between the demands of Rawls's ideal of public reason and those of partisanship, when the latter is intended as a normative ideal" (63). After all, suggests Bonotti, "[p]resenting partial values and demands in a way that takes into account general ends and the common good ... is the distinctive normative attribute of partisanship" (105). This might not seem like a surprising position to take if we consider how White and Ypi relate partisanship to public reason, but it is arguably not the popular view in contemporary analytic political theory.

Like White and Ypi's book, Bonotti's touches on a wide range of normatively relevant issues, including religion in the public sphere, free speech, and electoral systems, skilfully discussing these themes in relation to Rawls's canonical work and the topic of parties. All the while Bonotti operates with a quite heavily idealised normative conception of partisanship that is arguably rarely found in the "real world" in which he seeks to embed Rawls's philosophy. It is especially striking that Bonotti hardly acknowledges and explores the important tension between holding firm political commitments and public reason-associated norms of mutual listening and a disposition to compromise (see above), arguing instead that we should simply resist the "empiricization of the idea of the party" (105). This is a strange move given his intellectual ambition of bringing Rawls more into the "real world": while idealisation obviously facilitates connecting different theories in 
a clear manner, it is difficult to see how it would help connecting political philosophy with politics.

\section{From partisanship to party}

What is notable about the four works reviewed above is their strong focus on partisanship as political practice, and the relative neglect of party as political institution. To be sure, the two things hang together in important ways. Partisans make up a party, so it might be said that if we aim to make partisanship better via generating action-guiding ideals, we will eventually also make parties better. Furthermore, it seems clear that the emphasis on partisanship (at the expense of party) makes a great deal of sense in the generally more U.S.-centred work of Rosenblum and Muirhead. Given the rather loose organisation of parties in the U.S., and given that perhaps most contemporary democratic problems are associated with hyperbolic partisanship among voters, putting the emphasis on partisanship (not party) seems justified.

At the same time, however, the relative neglect of party that characterises the new political theory literature on parties, limits some of the theories' ability to travel beyond the American politics-context, as well as theories' capacity to speak to some of the most serious contemporary problems that plague party democracy. I think the latter point deserves special attention: for if the best party theories that are available do not squarely address some of the weightiest problems facing party democracy, then this at the very least calls for additional work that does address those problems (cf. Biezen and Saward 2008). This is not to say that the above-summarised normative theories lose their appeal because they pay too little attention to party institutions. Yet, it seems clear that complementary research is needed that focuses on pressing institutional challenges that undermine the capacity of parties to serve their most important functions, and possibly even undercut the emergence of desirable forms of partisanship. In this section, I want to make the case for such complementary research and then review the main recent theoretical works that have studied parties in terms of political institutions.

Institutional challenges: the rise of "cartel parties" and the crisis of party democracy

To begin, the institutional challenges I just alluded to arise from the long-term development of party organisations in established democracies, and have repeatedly been identified as main drivers behind the contemporary crisis of party (and, by extension, representative) democracy. They are problematised in one of the most influential empirical literatures in comparative politics scholarship on parties that charts the transformation of parties from "mass" to "catch-all" to "cartel" parties since the 1960s, with the latter model 
being "proposed as a means of drawing attention to patterns of interparty collusion or cooperation as well as competition, and as a way of emphasizing the influence of the state on party development" (Katz and Mair 2009, 755; Mair 2013).

Firstly, collusion and cooperation among major centre-left and centre-right parties has intensified as the post-war Keynesian growth regime transformed into a Hayekian one, and "the costs of providing public goods began to exceed the capacity of states to provide them" (Hopkin and Blyth 2019, 202). Under these conditions, many parties felt that they had "little choice but to become 'responsible' and make their peace with the capitalist class, while protecting themselves as best as they can from pressures to be 'responsive' to their members and voters" (Streeck 2014, 126; Mair 2013). This involved, first, a convergence of parties on the view that, whatever public goods states had produced in the past, the market could do it better. Think in this connection of 'Third Way' social democracy, which exchanged the ideology's traditional commitment to a primacy of politics over markets with a seemingly pragmatic endorsement of the primacy of markets over politics (Jackson 2013, 360; Faucher-King and Le Galès 2010). This approximation of right-of-centre views limited the space of policy competition and made the latter increasingly "focused on the efficient and effective management of the polity" (Katz and Mair 2009, 755). This is what Peter Mair $(2013,1)$ had in mind when he noted that today's parties "pursue a form of competition that is so lacking in meaning, that they no longer seem capable of sustaining democracy in its present form."

Secondly, in line with a belief in markets parties also acquiesced to, if not actively promoted, the externalisation of policy commitments, meaning most importantly the devolution of monetary policy to independent central banks. The result, as Hopkin and Blyth $(2019,204)$ note, is the "equivalent of binding quotas over the quality as well as quantity of polices that a group of parties can produce" and has the effect that "politicians are no longer responsible for either creating or managing economic outcomes." All of which enables them to be fiscally "responsible" instead of responsive to voters' demands, whilst steering clear of being directly accountable for it. Within the European Monetary Union, the European Central Bank is widely thought to perform this depoliticising function; but it is far from the only unelected body constraining parties' room for manoeuvre in the name of sound policy (see Bickerton et al. 2015).

Thirdly, in addition to ideological convergence and an externalisation of policy commitments, the cartelisation of parties came with an increased consolidation of the position of the party's professional arm at the expense of the (anyways decaying) partisan base. A key aspect of this is that parties have gradually obtained greater access to public funds, in order to solve the problem of not being able to generate sufficient funds through membership fees, and to reduce the "disparity of resources available to those in and out of government at any particular moment, in both respects by turning to the coffers of the state" (Katz and Mair 2009, 758). At the same time the remaining committed party activists have largely been disempowered, since they "are the ones most likely to make policy demands inconsistent with the 'restraint of trade' in policy that is implied by the cartel model" (Katz and Mair 2009, 759). Ironically, the means of disempowerment is often: 


\begin{abstract}
"the apparent democratization of the party through the introduction of such devices as postal ballots or mass membership meetings at which large numbers of marginally committed members or supporters - with their silence, their lack of capacity for prior independent (of the leadership) organization, and their tendency to be oriented more toward particular leaders rather than to underlying policies - can be expected to drown out the activists" (Katz and Mair 2009, 759).
\end{abstract}

Especially in postal ballots or membership ballots more generally, participation is rather "atomistic" in the sense that "individuals are isolated from one another and engaged in direct communication only with the party centre, in a fashion that inhibits their ability to act in common with each other" (Carty 2013, 19). This provides the party leadership "with the ability to manipulate a formally popular decision-making process, by ensuring that members' choices are constrained and limited to alternatives acceptable to the existing elite" (Carty 2013, 19).

To be sure, several of the theoretical accounts of party I have reviewed in the previous section are aware of these developments and make (occasional) references to the cartel party-literature, often in connection with defending partisanship against possible empirical objections and showing that existing empirical trends do not disallow the proposed ideals (e.g. White and Ypi 2016, 68-74). Yet the major new party theories hardly engage more closely with the distinctively institutional challenges that the rise of "cartel parties" raise, in particular the consolidation of the quasi-oligarchical rule of party elites through the twin mechanisms of (1) exploiting public resources to the benefit of the professionalised party organisation and (2) trying to "drown out the activists" who pose a potentially threat to the "restraints of trade" in policy through what are ultimately democratic means. But even more pertinently: it is unclear whether a theoretical ideal of partisanship, however attractive, can provide a solution to these problems. For even if we assume that partisans act in line with such an ideal, many of them would be silenced and marginalised by the organisational dynamics that entrench and stabilise the cartel party regime.

Institution-centred party theory

In my own work (for a book-length treatment, see Wolkenstein, forthcoming; also see Wolkenstein 2016; Wolkenstein 2019a, Wolkenstein 2019b), I have tried to take especially seriously the challenges presented by party cartelisation. My argument is, first, that parties' entrenchment via enhanced access to public resources (1) reinforces the case for investing our intellectual energies in theorising parties as institutions. For insofar as parties have taken decisive steps to minimise the risks and costs of losing office, writing their own salary checks and devising their own legal environment more generally (Katz and Mair 2009, 756), they have become major gatekeepers of power whose central role in 
organising the democratic political process cannot be ignored. New political actors, whether they choose to form a party themselves or not, will always be faced with an institutional environment that has been configured by older parties to make it difficult for others to challenge their power. To ignore this is to risk overlooking crucial power dynamics within contemporary representative democracies.

Second, given existing attempts to drown out activists via democratic procedures, reflection must be brought to bear on which alternative, actually empowering, models of intra-party democracy there are or could be. This is because there is nothing in-principle wrong with the idea of democratising parties. On the one hand, norms of participation are generally diversifying and shifting towards more direct and deliberative forms of political participation, which generally calls for making political parties more participatory (Wolkenstein, forthcoming; Wolkenstein 2016; Invernizzi-Accetti and Wolkenstein 2017; Wolkenstein 2019a). On the other hand, the activist partisan base should have greater influence on political decisions because it is (as noted) a key force when it comes to resisting the dynamics of cartelisation by articulating competing political demands from the bottom up, and more generally the lifeblood of a vibrant and societally-rooted party. The crucial question then becomes: how should internal party organisation be organised?

The answer I offer in my work - an optimistic one, to be sure - is that a deliberative conception of intra-party democracy can go a long way in addressing the just-described problems. By this I mean institutional designs that allow members to collectively deliberate over, question and criticise the proposals and decisions of party elites, as well as develop agendas and proposals of their own, rather than merely vote on proposals referred to them - or select candidates. What speaks for such a design is, first, that it can better unlock the critical potential of party activists than other forms of intra-party democracy: for in contrast to the potentially power-consolidating and status quo-reinforcing "postal ballots or mass membership meetings" many parties adopt (Katz and Mair 2009, 759), deliberative designs put critical reflection and debate front and centre, creating an opening to move away from the status quo.

Second, deliberative institutional designs are at once better aligned with the participatory incentives of increasingly individualist and self-realisation seeking publics, since they allow people to voice their views and be heard individually (Invernizzi-Accetti and Wolkenstein 2017), and it helps overcome the aforementioned problem that "individuals are isolated from one another and engaged in direct communication only with the party centre, in a fashion that inhibits their ability to act in common with each other" (Carty 2013, 19), since they are directed at creating compromises on collective agendas, proposals or single decisions. Thirdly, deliberative institutional designs within parties luckily need not be invented from scratch, but can take inspiration from decades of research on and experimentation with "democratic innovations" like deliberative mini-publics, participatory budgeting schemes, etc. (for an overview, see Smith 2009). In my work, I have suggested that parties can usefully draw on the knowledge available about such 
institutions, implementing, for example, problem-oriented discussion fora that are initiated by party members (for instance) with the aim of collectively devising a strategy for the party in a particular policy field without interference by party elites (Wolkenstein 2016). One could imagine designing these devices with an adjacent obligation for elected representatives to act on the recommendations put forward by the party members, which would significantly strengthen bottom-up linkage within the party.

There are many questions about the feasibility of such proposals, but I lack the space to go into this here. Suffice it to note that radical democratic transformations of parties seem possible even within long-established parties, as the recent reforms within the British Labour party show (Gerbaudo 2018). There is also a separate question whether such reforms are necessarily the best thing for a party or democracy at large; and there are certainly authors who, unlike myself, think that this is not the case. The argument that parties should resist internal democratisation has for instance been made by Frances Rosenbluth and Ian Shapiro in their provocative recent book Responsible Parties: Saving Democracy from Itself (2018), one of the few other recent contributions to the political theory of parties (though the book is framed more in terms of historical analysis than theory) that take the party qua institution seriously.

Paying no heed to the somewhat established finding that trends of internally democratising parties and dispersing power in a decentralised fashion have been exercises in sham democracy that only serve to empower party elites, Rosenbluth and Shapiro argue that increasing party members and citizens "direct control of decisions and politicians" has proven "self-defeating for most voters" (Rosenbluth and Shapiro 2018, 3), as it has led to the empowerment of "intense minorities" such as party activists who promote policies that most voters reject. Accordingly, Rosenbluth and Shapiro suggest that the radical opposite of internal party democratisation is more desirable: a party that is organised in a top-down fashion, with a strong leader who exercises firm control over MPs, who in turn form a disciplined and unified group that follows a common agenda and is unaffected by any kind of bottom-up pressures, be it from the wider membership or the citizenry as a whole. It is a "great paradox of politics," write the two authors, that in order for parties to produce good public policy, they must not themselves be internally democratic. This may be at odds with voters' participatory demands, and the general Zeitgeist of democratising established politics - but it will satisfy voters on the long run in terms of policy.

In Rosenbluth and Shapiro's view, the political system that has been most successful at maintaining the strong and responsible parties they regard as ideal is the British Westminster model (although they consider it now in decline because of decentralizing tendencies at the party level, notably in the Labour party after Jeremy Corbyn was elected as party leader). For decades if not centuries, they argue, Westminster has been structured around voter-benefitting competition between two large and disciplined parties. This is first because under Westminster, "any party seeking to gain or retain an electoral majority must present widely appealing policies"; secondly because "with only two parties in the game, political competition tends to be based on economic interests that are easy for voters to comprehend"; and thirdly because "single-member district systems create strong, 
unified opposition parties that can hold the government to account" (Rosenbluth and Shapiro 2018, 71-73). For all its weaknesses, there is probably no better party system. And in the end, Britain is a "well-run country, judging from the government's ability to implement policies with long-term benefits for most people most of the time over the long haul" (Rosenbluth and Shapiro 2018, 62). Or so Rosenbluth and Shapiro suggest.

The analysis comes with prescriptions. At a more general level, electoral systems around the world should be made more "British," and one should by all means refrain from democratising parties internally. More specifically and interestingly, Rosenbluth and Shapiro make thought-provoking suggestions about how to re-draw electoral districts in Single Member District-systems in order to incentivise parties to make better policies. They argue for establishing "larger, more diverse electoral districts that include urban, suburban, and rural voters in roughly the same proportion as in the country as a whole," for "When district residents have the same interests as the national median voter, internal party debates can focus on what is best for most rather than whose ox will gore someone else's" (Rosenbluth and Shapiro 2018, 239).

Much as Rosenbluth and Shapiro deserve to be applauded for their efforts to come up with concrete institutional recommendations, it remains open to question whether their proposed reforms are a sound remedy for the pathologies of contemporary representative democracy. Not only does it remain unclear whether they have correctly diagnosed the problem in the first place (their claim that parties are over-democratised runs counter to plenty of evidence showing that intra-party democracy is usually designed and implemented only to cement the power of the party elite, not to actually empower "intense minorities"). It is also highly doubtful that shaping electoral systems in such a way as to create more centrism is a plausible response to the ideological convergence of mainstream parties (see above) paired with greater polarisation on the fringes. For that would require that those who rebel against the mainstream - typically the supporters of "populist" parties on the left and right - all of a sudden recognise that they profit from centrism, which seems like a highly unrealistic expectation.

\section{The party as revolutionary agent}

The final recent addition to the body of party theory literature, Jodi Dean's Crowds and Party (2016), pulls in an altogether different direction, but also thinks of parties in terms of institutions or, perhaps even more accurately, collective agents. Dean's political aims are diametrically opposed to Rosenbluth and Shapiro's: instead of proposing reforms to party organisations in order to promote political centrism, Dean seeks to defend the party form as a potent vehicle of radical left-wing political protest and resistance to what she calls "communicative capitalism." To "make a party of communists seem compelling to more of us again," explains Dean, "I offer an approach to party inspired by the crowd. Faithful to the egalitarian rupture of the crowd event, the communist party holds open the gap through which the people," understood as "a revolutionary alliance of the oppressed," 
"appear as the political subject" (Dean 2016, 28). The idea is to use the party as a way of empowering crowds, "the proletarianized many, those whose communicative engagements are expropriated from them in processes of accumulation and dispossession that benefit capital as a class" (Dean 2016, 28), by allowing them to conceive themselves as the people.

In essence, Dean recommends the party as the antidote to the individualism of the "dominant ideology" of capitalist liberalism. "Capitalism," she argues, "strives to separate and individuate us, to instil in us the conviction that self-interest matters above all else, that freedom results from individual choices made for individual goals" (Dean 2016, 260). And "When leftists assume the individualism of the dominant [capitalist] ideology, reiterating its emphases on uniqueness and trying to cultivate a politics out of individuated decisions, [they] undermine [their] own best impulses to collectivity and egalitarianism." The political party, giving enduring shape to a collective political project, can allow the radical left to both overcome the politically debilitating implications of its internal fragmentation and to move from occasional moments of promise - as experienced in largescale protests like Occupy - to even greater mobilisation and the effective exercise of collective agency. It "enables the crowd to endure as a rupture with capitalism," in Dean's words (Dean 2016, 261), thus making possible what radical approaches to politics that reject the party form as overly institutionalist, insufficiently spontaneous or even potentially repressive cannot achieve: to create a collective agent that is sufficiently durable to actually challenge existing structural power (this dovetails with Muirhead's reflections on partisan loyalty; see above.)

And this leads to Dean's major contribution: though she barely provides more concrete organisational recommendations, she manages to defend in a rigorous fashion the ultimate importance of parties to radical political projects. This contribution is important because the larger part of more radical political theorising is, as Dean rightly criticises, too focused on non-institutionalised and spontaneous modes of political action. As I noted in the introduction, "phenomena such as civil disobedience, irregular and informal movements, ... protests, insurgencies, street fighting, and illegal upheavals" (Kalyvas 2008,297 ) are often considered more important if not normatively superior to the more "normal" politics of partisan conflict. Yet the more enduring and coordinated forms of collective agency are arguably better-placed to affect lasting social change, and here party is indeed a promising place to search for organisational inspiration (cf. Gerbaudo 2018). In its own way, Dean's proposal might also be seen as a response to the empirical challenges of party cartelisation I have described at the beginning of this section. For one, it seeks to show how radical alternatives to the status quo can become politically salient, against tendencies of policy convergence and the externalisation of policy commitments. And it is less concerned with designing ambitious party reforms - like the ones proposed by myself - than with preparing the revolution. Which, irrespective of whether one thinks it is desirable, might even be the more realistic approach to changing the status quo. 


\section{Conclusion}

"Across the West," remarks one observer, "and in Europe in particular, we are witnessing a resurgence of the political party. Both old parties, like Labour in Britain, and new ones, like Podemos in Spain and France Insoumise, have experienced spectacular growth in recent years, while also undergoing important organizational innovations" (Gerbaudo 2018). This is a good time for political theorists to study parties. Democratic theorists are especially well-placed to make better sense of the "spectacular growth" of some parties and the "organizational innovations" they experiment with, as well as propose useful institutional alternatives for parties that struggle politically. They can draw on multiple normative and empirical literatures that are concerned with understanding and improving democratic institutions, without necessarily being tied to a single empirical or theoretical paradigm (Biezen and Saward 2008). While it is critically important to keep an eye on practices of partisanship along the way, the most urgent questions of the day seem to be about institutional design. The first wave of party theory has established the ideal shape and democratic value of partisanship, it is now time to concentrate more on reforming or even reinventing the party as institution. To some, this might seem a hopeless task, given the tendencies described in the article's second part; but such pessimism is misplaced in light of countervailing tendencies of party resurgence. In each crisis there may also be opportunity.

\section{References}

Bader, V. (2014). Crisis of political parties and representative democracies: rethinking parties in associational, experimentalist governance. Critical Review of International Political Philosophy, vol. 17(3), pp. 350-376. https://doi.org/10.1080/ 13698230.2014.886380

Bächtiger A., Dryzek J.S., Mansbridge, J., and Warren, M.E., eds. (2018). Oxford Handbook of Deliberative Democracy. Oxford: Oxford University Press.

Berman, S. (2006). The Primacy of Politics. Cambridge: Cambridge University Press.

Bickerton, C.J., Hodson, D., and Puetter, U. (2015). The New Intergovernmentalism: European Integration in the Post-Maastricht Era, Journal of Common Market Studies, vol. 53(4), pp. 703-722. https://doi.org/10.1111/jcms.12212

Biezen, I.v. and Saward, M. (2008). Democratic Theorists and Party Scholars: Why They Don't Talk to Each Other, and Why They Should. Perspectives on Politics, vol. 6(1), pp. 21-35. https://doi.org/10.1017/s1537592708080043

Bonotti, M. (2017). Partisanship and Political Liberalism in Diverse Societies. Oxford: Oxford University Press. 
Burke, E. ([1770] 1998). A Philosophical Enquiry into the Origin of Our Ideas of the Sublime and Beautiful and Other Pre-revolutionary Writings. London: Penguin Classics.

Butler, J. (2015). Notes Toward a Performative Theory of Assembly. Cambridge, MA: Harvard University Press.

Carty, R.K. (2013). Are Political Parties Meant to be Internally Democratic? In: Katz, R.S. and Cross, W., eds., The Challenges of Intra-Party Democracy. Oxford: Oxford University Press. https://doi.org/10.1093/acprof:oso/9780199661879. 003.0002

Celikates, R. (2016). Rethinking Civil Disobedience as a Practice of Contestation - Beyond the Liberal Paradigm, Constellations, vol. 23(1), pp. 37-45. https://doi.org/10.1111/1467-8675.12216

Dean, J. (2016). Crowds and Party. London: Verso.

Ebeling, M. (2016). Epistemic Political Egalitarianism, Political Parties, and Conciliatory Democracy. Political Theory, vol. 44(5), pp. 629-656. https://doi.org/10.1177/ 0090591715605352

Edsall, T.B. (2019). No Hate Left Behind: Lethal partisanship is taking us into dangerous territory. The New York Times [online]. Available at: https://www.nytimes.com/2019/03/13/opinion/hate-politics.html?fbclid=IwAR0Mug4vv DuVFs3L7WGX5iktZEs8DCEu8QnCiMuSyy7t6vr5aindzly3zgM [Accessed 14 April 2019].

Faucher-King, F. and Le Galès, P. (2010). The New Labour Experiment: Change and Reform Under Blair and Brown. Stanford, CA: Stanford University Press.

Gerbaudo, P. (2018). The Return of the Party. Jacobin [online]. Available at: https:/www.jacobinmag.com/2018/10/mass-party-labour-podemos-neoliberalism [accessed 3 April 2019].

Hopkin, J. and Blyth, M. (2019). The Global Economics of European Populism: Growth Regimes and Party Systems Change in Europe. Government and Opposition, vol. 54(2), pp. 193-225. https://doi.org/10.1017/gov.2018.43

Ignazi, P. (2017). Party and Democracy: The Uneven Road to Party Legitimacy. Oxford: Oxford University Press.

Invernizzi-Accetti, C. and Wolkenstein, F. (2017). The Crisis of Party Democracy, Cognitive Mobilization, and the Case for Making Parties More Deliberative, American Political Science Review, vol. 111(1), pp. 97-109. https://doi.org/10.1017/ s0003055416000526

Jackson, B. (2013). Social Democracy. In: Freeden, M. and Stears, M., eds., The Oxford Handbook of Political Ideologies. Oxford: Oxford University Press, pp. 348-363. https://doi.org/10.1093/oxfordhb/9780199585977.013.0030

Kalyvas, A. (2008). Democracy and the Politics of the Extraordinary: Max Weber, Carl Schmitt and Hannah Arendt. Cambridge: Cambridge University Press.

Katz, R. and Mair, P. (2009). The Cartel Party Thesis: A Restatement. Perspectives on Politics, vol. 7(4), pp. 753-766. https://doi.org/10.1017/s1537592709991782 
Landis, J.L. (2018). Whither Parties? Hume on Partisanship and Political Legitimacy. American Political Science Review, vol. 112(2), pp. 219-230. https://doi.org/ $10.1017 / \mathrm{s} 0003055417000545$

Mair, P. (2013). Ruling the Void: The Hollowing of Western Democracy. London: Verso. Muirhead, R. (2006). A Defence of Party Spirit. Perspectives on Politics, vol. 4(4), pp. 713-727. https://doi.org/10.1017/s1537592706060452

Muirhead, R. (2010). Can Deliberative Democracy be Partisan?, Critical Review, vol. 22(2-3), pp. 129-157. https://doi.org/10.1080/08913811.2010.508631

Muirhead, R. (2014). The Promise of Party in a Polarized Age. Cambridge, MA.: Harvard University Press.

Näsström, S. (2015). Democratic Representation Beyond Election. Constellations, vol. 22(1), pp. 1-12. https://doi.org/10.1111/1467-8675.12123

Rawls, J. (1993). Political Liberalism. New York, NY: Columbia University Press.

Rehfeld, A. (2009). Representation Rethought: On Trustees, Delegates, and Gyroscopes in the Study of Political Representation and Democracy. American Political Science Review, vol. 103(2), pp. 214-230. https://doi.org/10.1017/s000305540909 0261

Rosanvallon, P. (2008). Counter-Democracy: Politics in an Age of Distrust. Cambridge: Cambridge University Press.

Rosenblum, N. (2008). On the Side of the Angels. Princeton, NJ: Princeton University Press.

Rosenbluth, F.M. and Shapiro, I. (2018). Responsible Parties: Saving Democracy from Itself. New Haven, CT: Yale University Press.

Saward, M. (2010). The Representative Claim. Oxford: Oxford University Press.

Scheuerman, W.E. (2016). Civil Disobedience in the Shadows of Postnationalization and Privatization. Journal of International Political Theory, vol. 12(3), pp. 237-257. https://doi.org/10.1177/1755088215617192

Schweber, H. (2016). The Limits of Political Representation. American Political Science Review, vol. 110(2), pp. 382-396. https://doi.org/10.1017/s0003055416000137

Smith, G. (2009). Democratic Innovations: Designing Institutions for Citizen Participation. Cambridge: Cambridge University Press.

Smith, W. (2017). Civil disobedience as transnational disruption. Global Constitutionalism, vol. 6(3), pp. 477-504. https://doi.org/10.1017/s204538171700020x

Streeck, W. (2014). The Politics of Exit. New Left Review, vol. 88(July/August), pp. 121129.

Teorell, J. (1999). A Deliberative Defence of Intra-Party Democracy. Party Politics, vol. 5(3), pp. 363-382. https://doi.org/10.1177/1354068899005003006

Wolkenstein, F. (Forthcoming). Rethinking Party Reform. Oxford: Oxford University Press.

Wolkenstein, F. (2019a). Party Reforms and Electoral Systems: Proportional Representation is More Hospitable to Internal Democratisation. Representation. Online First. https://doi.org/10.1080/00344893.2019.1652204. 
Wolkenstein, F. (2019b). Agents of Popular Sovereignty. Political Theory, vol. 47(3), pp. 338-362. https://doi.org/10.1177/0090591718786232

Wolkenstein, F. (2016). A Deliberative Model of Intra-Party Democracy. Journal of Political Philosophy, vol. 24(3), pp. 297-320. https://doi.org/10.1111/jopp.12064 